\title{
Acaricidal Activity of Essential Oils of Chamomile, Marjoram and Eucalyptus against the Two-Spotted Spider Mite, Tetranychus urticae Koch: Biology and Enzymes
}

\author{
A. M. R. Afify ${ }^{*}$; Fatma S. Ali**; M. A. Mohamed ${ }^{*}$ and A. F. Turky ${ }^{* *}$ \\ "Biochemistry Dept., Fac. of Agric., Cairo Univ., moneimafify@yahoo.com \\ ${ }^{* *}$ Zoology and Nematology Dept., Fac. of Agric., Cairo Univ.
}

\begin{abstract}
Different concentrations of three essential oil extracts $(0.5,1,2,3$ and 4\%) were used against Tetranychus urticae. (Koch) Chamomile; Chamomilla recutita (L.), proved to be the most efficient agent against $T$. urticae followed by Marjoram; Marjorana hortensis (L.), and Eucalyptus (Eucalyptus sp.) The LC L $_{50}$ values of these oils were $0.651 \& 1.17$; $1,84 \& 6.26$ and $2.18 \& 7.33$ for adults and eggs, respectively. Herein, the bioassay experiments of the two essential oils, Chamomile and Marjoram showed relationship between essential oil contents and activity of enzyme glutathione S-transferase, non specific esterase and alkaline phosphatase in T.urticae. GC-MS analysis of C. recutita and M. hortensis proved the presence of 13 and 14 essential oil components, respectively. The major essential oil contents of $C$. recutita are $\alpha$-Bisabolol oxide A (35.25\%), and Trans- $\beta$-farersene (7.98\%), while the main components of $M$. hortensis are Terpinen-4-ol (23.86\%), P-cymene (23.40\%) and Sabinene (10.90\%). The major components of both plant extracts (Terpinen-4-ol 23.86\% and $\alpha$-Bisabolol oxide A 35.25\% essential oils) may be responsible for the activity of enzymes of T. urticae (glutathione S-transferase, non specific esterase and alkaline phosphatase).
\end{abstract}

Key Words: Tetranychidae, Plant essential oils, Enzymes, Glutathione S-transferase, Non specific esterase and Alkaline phosphatase.

\section{INTRODUCTION}

The two-spotted spider mite, Tetranychus urticae Koch is one of the most important pests responsible for yield losses to many horticultural ornamental and agronomic crops. A major problem in the control of T. urticae is the response to develop resistance to many acaricides (Stumpf and Nauen, 2002).

For several years, chemical control of mites has been extensively practiced in Egypt to check mite population increase. Resistance problems and high residual levels in food products may hinder its marketing. Such undesirable consequences have caused alienating effects on the irrational use of chemical agents (Ali, 2004).

Therefore, the use of essential oils of plant extracts in pest management programs has recently attracted the attention of many scientists. Pesticides of plant origin seem to be recommended as they generally have a very short persistence in the plant (Isman, 1997 and Carbaras et al., 2002).

However, the selectivity of these products has to be strictly evaluated for different species of natural enemies as deleterious or some times positive effects were recorded among the natural enemies complex (Stark et al., 1990, 1992, Tsolakis and Ragusa, 1999).

Glutathione S-transferases (GSTs) catalyse the conjugation of a large variety of compounds bearing an electrophilic site, with reduced glutathione (Mannervik and Danielson, 1988). In insects they represent a very interesting detoxification mechanism due to their involvement in tolerance to insecticides (Motoyama and Dauterman, 1980 and Kostaropoulos et al., 2001).

It is reported that most xenobiotics are subjected to enzymatic modification after penetration of the insect body. It had been clearly demonstrated that several enzymatic system in insect such as esterase and phosphatase can play a vital role in the detoxification of xenobiotics to nontoxic materials (Busvine, 1971, and Croft, 1977).

Herein, this study aimed to evaluate the ability of plant extracts essential oils against $T$. urticae. The biochemical changes due to treatment of $T$. urticae by $\mathrm{LC}_{50}$ of the tested oils were evaluated. In this respect, some detoxifying enzymes such as glutathione S-transferase, nonspectific esterase and alkaline phosphatase were manipulated in T.urticae.

\section{MATERIALS AND METHODS}

\section{Test mite}

T. urticae was collected from infested cucumber plants (Cucumis sativus L.). Bean (Phaseolus vulgaris L.) seeds were planted in plastic pots (14 cm diameter) at a rate of 4-5 seeds per pot, and seedlings were infested with $T$. urticae adults from this culture, adult mite were transferred to aluminum.

Pans ( $30 \times 20 \times 70 \mathrm{~cm})$ on fresh leaves of beef steak (Acalyph wilkesiana L.) placed upside down on wet cotton pads. Water was added when needed 
maintaining suitable moisture and kept in incubator at $25 \pm 2^{\circ} \mathrm{C}$ and $70 \pm 5 \%$ R.H.

\section{Source of sample}

Three essential oils extracted from plants belong to three different families of which Marjoram (Marjorana hortensis) Family Lamiaceae and Chamomile (Chamomilla recutita) family Asteraceae were collected from Sekam farm in Belbase (Sharqia Governorate). Leaves of Eucalyptus (Eucalyptus sp.) Family Myrtaceae, were collected from the Faculty of Agriculture farm of Cairo University.

\section{Preparation of essential oils}

The whole plants (herbs) of Marjoram and Chamomile and leaves of Eucalyptus were dried for a week at room temperature, and then crushed according to Aslan et al. 2004. Essential oils were extracted from by hydro distillation (deionized water for $4 \mathrm{hr}$ ) under vacuum according to (Hoelzl and demuth, 1975). All oils and components were kept under freezing until used. Series of aqueous concentrations of each essential oil were prepared with Triton X-100 as surfactant at a rate of $0.1 \%$.

\section{Treatment of eggs}

Leaf discs, $3 \mathrm{~cm}$ diameter, of Beef steak leaves were used as substrate to oviposition. Four leaf discs were used for each treatment and five mite females were transferred for each disc and left $24 \mathrm{~h}$ to lay eggs, then females were removed. Thereafter, fourty eggs, on four discs, were treated with one of the five concentrations $(0.5,1,2,3$ and $4 \%)$. Eggs were sprayed by a glass atomizer, with a serial of concentrations for each essential oil; $1 \mathrm{ml} / 200 \mathrm{~cm}$ of the solution was used. (Tsolakis \& Ragusa, 2008). Eggs were incubated at $25 \pm 2{ }^{\circ} \mathrm{C}$ for seven days till hatching. The numbers of hatching and non hatching eggs were recorded.

\section{Treatment of adult females}

T. urticae females, 3 days old, were obtained by placing 100 dueto- nymphs from the culture, and on excised Beef steak leaves placed on wet cotton pads in Petri dishes. The emerged females and males were transferred to new Beef steak leaves for 2-3 days and allowed to mate. Afterwards, fourty females were transferred equally to four discs, $3 \mathrm{~cm}$ diameter, and then treated with one of the previous treatments. Control treatment was operated by Triton X-100 at a rate of $0.1 \%$. Mortality was estimated for the adult females after $24 \mathrm{~h}$ of spraying and estimated by Abbot's formula (1925) and $\mathrm{LC}_{50}, \mathrm{LC}_{90}$ and slope values were estimated according to Finney (1971).

\section{Biochemical assay \\ Preparation of samples for enzymes determination}

Adult females $(10 \mathrm{mg})$ were homogenized in $1 \mathrm{ml}$ distilled water in ice for three minutes using Teflon Homogenizer. The homogenates were centrifuged at 3500 r.p.m for 10 minutes at $4^{\circ} \mathrm{C}$ and the supernatants were used directly to determine the activity of alpha and beta esterase, glutathione S-transferaes and alkaline phosphatase according to Sakunwarin et al., (2004).

\section{Determination of Non specific esterase}

$\alpha$-esterase and $\beta$-esterase were determined according to the method of Van Asperen (1962).

\section{Determination of Glutathione-S-transferase}

Glutathione-S-transferase (GST) was measured according to the method described by Habig et al. (1974) who used 1-chloro -2, 4 Dinitro benzene (CDNB).

\section{Determination of Alkaline phosphatase}

Alkaline phosphatase was determined according to the method described by Powell and Smith (1954).

\section{Statistical Analysis}

Experimental data were statistically analyzed by using Costa software (cohort software, Berkeley). Significance of results was obtained by randomized one way ANOVA, and the means were separated using the Duncan's multiple range test (1955) at $\mathrm{p}<0.01$.

\section{RESULTS AND DISCUSSION}

Data presented in table (1) demonstrate that Chamomile essential oil extract was the most effective against $T$. urticae, which enhanced the highest adult female mortality and lowest egg hatchability. Adult mortality percentages after $24 \mathrm{~h}$ were 42.5, 75, 90, 95 and $100 \%$ for Chamomile by spraying the different concentrations $0.5,1,2,3$ and $4 \%$, respectively. The percentage corresponding mortalities for Marjoram were 20, 30, 42.5, 72.5, and $85 \%$, while $17.5,27.5,40,70$, and $80 \%$ for Eucalyptus, respectively. Hatchability percentages after six days were $75,55,30,16$ and $10 \%$ for Chamomile; 95, 87.5, 80, 72.5, 57.5\% for Marjoram and $95,92.5,82.5,77.5$ and $67.5 \%$ for Eucalyptus respectively, for control treatment (Triton X-100 $0.1 \%$ ), adult mortality recorded $10 \%$ and egg hatchability $95 \%$.

The present results are in agreement with that of Baker (2003) who studied the evaluation of the 
acaricidal activity of some essential oils against $T$. urticae as the percentage mortality of adults at both 2 and 4\% concentrations recorded 38 and $78 \%$, respectively for Eucalyptus and recorded $70 \%$ at the $3 \%$ concentration for Marjoram . It is also in agreement with that of El-Halawany and Sawires (1988) who tested six essential volatile oils against T. urticae, whereas repellency percentage ranged between $70 \%$ and $85 \%$ for Marjoram treatment. Mansour et al., (1986) reported that 0.5, 1and 2\% concentrations of Ocimum basilicum oil reduced T. cinnabarinus female's fecundity by 15,38 and $92 \%$, respectively. On the other hand, the same concentration of Chamomile oil reduced female's fecundity by $42.5,75$ and $90 \%$, respectively.

Table 2 proved that Chamomile essential oil extract was the most potent followed by Marjoram and Eucalyptus. The $\mathrm{LC}_{50}$ values after $24 \mathrm{~h}$ for adults were $0.65,1.84$ and $2.18 \%$, respectively, while for eggs $1.17,6.26$ and $7.33 \%$ were recorded after seven days. The slope values of the regression line were $2.41,2.53$ and 2.49 for adults and 2.28, 1.89 and 2.15 for eggs, respectively. $\mathrm{LC}_{90}$ values were $2.27,5.91$ and $7.13 \%$ for adults and 4.34 , 9.81 and $28.95 \%$ for eggs, respectively.

The present results were in agreement with the

Table (1): Effect of three essential oil plant extracts against T.urticae egg hatchability and adult mortality.

\begin{tabular}{ccccccc}
\hline \multirow{2}{*}{$\begin{array}{c}\text { Conc. } \\
\%\end{array}$} & \multicolumn{2}{c}{$\begin{array}{c}\text { Chamomilla } \\
\text { recutita }\end{array}$} & \multicolumn{2}{c}{$\begin{array}{c}\text { Marjorana } \\
\text { hortensis }\end{array}$} & \multicolumn{2}{c}{ Eucalyptus sp. } \\
\cline { 2 - 7 } & $\begin{array}{c}\text { Adult } \\
\text { mort. }\end{array}$ & $\begin{array}{c}\text { hgg } \\
\text { hatch. }\end{array}$ & $\begin{array}{c}\text { Adult } \\
\text { mort. }\end{array}$ & $\begin{array}{c}\text { Egg } \\
\text { hatch. }\end{array}$ & $\begin{array}{c}\text { Adult } \\
\text { mort. }\end{array}$ & $\begin{array}{c}\text { Egg } \\
\text { hatch. }\end{array}$ \\
\hline 0.5 & 42.5 & 75.0 & 20.0 & 95.0 & 17.5 & 95.0 \\
1 & 75.0 & 55.0 & 30.0 & 87.5 & 27.5 & 92.5 \\
2 & 90.0 & 30.0 & 42.5 & 80.0 & 40.0 & 82.5 \\
3 & 95.0 & 16.0 & 72.5 & 72.5 & 70.0 & 77.5 \\
4 & 100.0 & 10.0 & 85.0 & 57.5 & 80.0 & 67.5 \\
Control & 10.0 & 95.0 & 10.0 & 95.0 & 10.0 & 95.0 \\
\hline
\end{tabular}

Conc. $=$ Concentration mort. $=$ mortality hatch. $=$ hatchability data cited by Kawka (2004) who studied the effect of Chamomile (Matricaria recutita [recutita]) extracts from fresh and dry flowers on T. urticae; mortality of immatures was the highest on leaves treated with extract from dried flowers.

Table 3 showed that the activity of GST significantly increased after treatment with $\mathrm{LC}_{50}$ and the activity was $881.3,1003,771.7$ and $771.3 \mathrm{n}$ $\mathrm{mole} / \mathrm{min} / \mathrm{mg}$ for Marjoram, Chamomile, positive control (Triton.X-100) and negative control, respectively. Regarding $\alpha, \beta$ esterase, it significantly increased in 19.9 and $7.85 \mathrm{mg} \alpha, \quad \beta$-naphthol released $/ \mathrm{min} / \mathrm{g}$.b.wt treated with $\mathrm{LC}_{50}$ of Marjoram compared with other treatments. Alkaline phosphatase significantly decreased in 4.03 and 4.66 U/g.b.wt treated with $\mathrm{LC}_{50}$ of Marjoram and Chamomile compared with other treatments.

Similar data were obtained by Cao et al. (2003) who studied the efficiency of four essential oil extracts from Stellera chamaejasme L. [Wikstroemia chamaejasme (L.)] against. Tetranychus viennensis Zacher [Amphitetranychus viennensis (Zacher)]. The effect of the essential oil extracts on the three most important enzyme systems of T. viennensis was also studied. The extracts of $S$. chamaejasme exhibited strong pesticidal activities against $T$. viennensis.

Table (2): Toxicity of three essential oil plant extracts against $T$. urticae adult females and eggs.

\begin{tabular}{lcccccc}
\hline \multirow{2}{*}{$\begin{array}{c}\text { Toxicity } \\
\text { parameter }\end{array}$} & $\begin{array}{c}\text { Chamomilla } \\
\text { recutita }\end{array}$ & \multicolumn{2}{c}{$\begin{array}{c}\text { Marjorana } \\
\text { hortensis }\end{array}$} & \multicolumn{2}{c}{$\begin{array}{c}\text { Eucalyptus } \\
\text { sp. }\end{array}$} \\
\cline { 2 - 7 } & Adults & Eggs & Adults & Eggs & Adults & Eggs \\
\hline LC $_{50}$ & 0.65 & 1.17 & 1.84 & 6.26 & 2.18 & 7.33 \\
Lower limit & 0.46 & 0.94 & 1.53 & 4.18 & 1.82 & 4.74 \\
Upper limit & 0.82 & 1.45 & 2.21 & 25.40 & 2.67 & 39.05 \\
Index & 100.00 & 100.00 & 35.44 & 19.11 & 29.82 & 16.31 \\
Slope & 2.41 & 2.28 & 2.53 & 1.89 & 2.49 & 2.15 \\
LC $_{90}$ & 2.27 & 4.34 & 5.91 & 9.81 & 7.13 & 28.95 \\
\hline
\end{tabular}

Table (3): Effect of $24 \mathrm{~h}$ treatment by $\mathrm{LC}_{50}$ of essential oils on enzyme activities of $T$. urtice adult.

\begin{tabular}{lcccc}
\hline \multirow{2}{*}{\multicolumn{1}{c}{ Enzymes }} & \multicolumn{4}{c}{ Treatment } \\
\cline { 2 - 5 } & $\begin{array}{c}\text { Negative } \\
\text { Control }\end{array}$ & $\begin{array}{c}\text { Positive Control } \\
\text { (Triton X-100) }\end{array}$ & $\begin{array}{c}\text { Marjorana } \\
\text { hortensis }\end{array}$ & $\begin{array}{c}\text { Chamomilla } \\
\text { recutita }\end{array}$ \\
\hline Glutathione s-transferase (n mole/min/mg) & $771 \pm 38.5^{\mathrm{c}}$ & $771.7 \pm 10.1^{\mathrm{c}}$ & $881.3 \pm 8.5^{\mathrm{b}}$ & $1003 \pm 15.3^{\mathrm{a}}$ \\
$\alpha$ - Esterase $(\mathrm{mg}-\alpha$ - naphthol released/min/g.b.wt) & $2.79 \pm 0.21^{\mathrm{c}}$ & $8.62 \pm 0.13^{\mathrm{b}}$ & $19.9 \pm 1.34^{\mathrm{a}}$ & $8.99 \pm 0.115^{\mathrm{b}}$ \\
$\beta$-Esterase $(\mathrm{mg} \beta$-naphthol released/min/g.b.wt) & $0.904 \pm 0.007^{\mathrm{c}}$ & $2.72 \pm 0.05^{\mathrm{b}}$ & $7.85 \pm 0.138^{\mathrm{a}}$ & $2.65 \pm 0.05^{\mathrm{b}}$ \\
Alkaline phosphatase (U/g.b.wt) & $7.15 \pm 0.17^{\mathrm{a}}$ & $5.7 \pm 0.11^{\mathrm{b}}$ & $4.03 \pm 0.15^{\mathrm{d}}$ & $4.66 \pm 0.06^{\mathrm{c}}$ \\
\hline
\end{tabular}

Mean bearing different subscript are significantly different at $\mathrm{P}<0.01$

Data are presented as mean \pm SD. 
The activities of protease, Glutathione S-transferase and esterase isoenzymes were induced with chloroform + extract direct treatment, while ingestion of leaves with chloroform inhibited esterase isoenzyme activity only. Also, Wang et al., (2007) tested several important enzyme systems in T. cinnabarinus treated with petroleum ether extract of Jungians raga leaves. The extracts had strong acaricidal activities against $T$. cinnabarinus as it induced strong activities of glutathione-S-transferase in the mite. Because the two essential oil extracts of Chamomile and Marjoram had most potent activities against T.urticae, the detailed chemical composition of the two essential oils were analyzed by GC/MS as shown in tables (4) and (5). GC-MS analysis of C.recutita (table, 4): proved the presence of thirteen components. The major essential oil contents of C. recutitae $\alpha$-bisabolol oxide A (35.25\%), and trans $\beta$-farersene (7.98\%). The present result is in agreement with that of Pino et al. (2002) who studied the chemical composition of $C$. recutita essential oil by GC/MS which contained $\alpha$-bisabolol oxide A (43.8\%) as the major one. GC-MS analysis of $M$. hortensis (Table, 5) proved the presence of fourteen components, respectively. The major essential oil contents are Terpinen-4-ol (23.86\%), $\rho$-cymene $\quad(23.40 \%), \quad$ Sabinene $\quad(10.90 \%)$, $\gamma$-Terpinene $(9.034 \%), \alpha$-Terpinene (6.421). The present results are in agreement with those documented by .Ma et al., (2004) who found that the highest effect of terpinene -4-ol on esterase activity was noted during recover stage of housefly adult (Musca domesticae). Ma et al., (2008) reported that activities of both acid phosphatase (ACP ) and alkaline phosphates ( AKP) in insects were induced by terpinen-4-ol, but ACP was inhibited at paralysis stage .The activity of Glutathione S-transferase (GSTs) were inhibited in exciting, convulsing and paralysis stages of 5th star larvae of M.separata, but it gradually recovered in the recovery stage. This affected the metabolism and activity of phophatase and esterase enzymes. On the other hand the inhibited insect GST will inhibit normal metabolism. The major essential oil of marjoram was Terpinen-4ol $(23.86 \%)$, (Fig.1\&Table 6) and in chamomile was $\alpha$-Bisabolol oxide A (35.25\%), (Fig.2\&Table 6) may be responsible for controlling T. urticae. These points need further investigations in the future to prove our suggestions by using individual component and its effect on the enzymes of $T$. urticae. Even this suggestion was approved by Ma et al., (2004) and Ma et al., (2008) who cited that Terpinen-4-ol hydrolyzed metabolism by activitying phophatase .in addition that Terpinen-4-ol inhibited protection and immunity system and speeded up death of insects.
Table (4): Composition of chamomile (Chamomilla recutita (L.) essential oil

\begin{tabular}{|c|c|c|c|c|}
\hline compound & $\mathrm{R}_{\mathrm{t}}(\min )$ & $\% \quad 1$ & M. formula & M.W. \\
\hline$\beta$-Ocimene & 13.597 & 1.435 & $\mathrm{C}_{10} \mathrm{H}_{16}$ & 136.23 \\
\hline$\gamma$-terpinene & 13.963 & 0.678 & $\mathrm{C}_{10} \mathrm{H}_{16}$ & 136.23 \\
\hline Artemisia ketone & 14.255 & 1.305 & $\mathrm{C}_{10} \mathrm{H}_{16} \mathrm{O}$ & 152.23 \\
\hline Bicycloe lemene & 26.603 & 0.739 & $\mathrm{C}_{15} \mathrm{H}_{24}$ & 204.00 \\
\hline Trans $\beta$-farnesene & 34.379 & 7.758 & $\mathrm{C}_{15} \mathrm{H}_{24}$ & 204.19 \\
\hline Germacrene-D & 34.819 & 0.122 & $\mathrm{C}_{15} \mathrm{H}_{24}$ & 204.19 \\
\hline$\alpha$-farnesene & 36.319 & 1.399 & $\mathrm{C}_{15} \mathrm{H}_{24}$ & 204.19 \\
\hline$\alpha$-calacorene & 36.702 & 1.534 & $\mathrm{C}_{15} \mathrm{H}_{24}$ & 204.35 \\
\hline $6 \alpha$-Cadina-4,9-diene & 43.843 & 0.893 & $\mathrm{C}_{15} \mathrm{H}_{24}$ & 204.35 \\
\hline$\alpha$-bisabolol oxide A & 52.128 & 35.251 & $\mathrm{C}_{15} \mathrm{H}_{26} \mathrm{O}$ & 238.54 \\
\hline $\begin{array}{l}\text { Hexahydrofarnesyl } \\
\text { acetone }\end{array}$ & 53.690 & 1.249 & $\mathrm{C}_{18} \mathrm{H}_{36} \mathrm{O}$ & .00 \\
\hline Tricosane & 67.160 & 0.839 & $\mathrm{C}_{23} \mathrm{H}_{48}$ & 324.63 \\
\hline Heptacosane & 70.856 & 1.636 & $\mathrm{C}_{27} \mathrm{H}_{56}$ & 380.00 \\
\hline
\end{tabular}

$\mathrm{R}_{\mathrm{t}}=$ Retention time $\quad$ M. formula $=$ Molecular formula M.W. = Molecular weight

Table (5): Composition of Marjoram (Marjorana hortensis (L.)) essential oil

\begin{tabular}{lcccc}
\hline Compound & $\mathrm{R}_{\mathrm{t}}$ (min.) & $\%$ & M.formule & M.W. \\
\hline$\alpha$-pinene & 8.476 & 1.757 & $\mathrm{C}_{10} \mathrm{H}_{16}$ & 136.23 \\
Sabinene & 10.473 & 10.904 & $\mathrm{C}_{10} \mathrm{H}_{16}$ & 136.24 \\
$\beta$-Myrcene & 11.125 & 1.386 & $\mathrm{C}_{10} \mathrm{H}_{16}$ & 136.24 \\
p-cymene & 13.093 & 23.404 & $\mathrm{C}_{10} \mathrm{H}_{14}$ & 134.22 \\
$\gamma$-terpinene & 14.512 & 9.034 & $\mathrm{C}_{10} \mathrm{H}_{16}$ & 136.23 \\
Cis $\beta$-Terpineol & 15.039 & 1.152 & $\mathrm{C}_{10} \mathrm{H}_{18} \mathrm{O}$ & 154.24 \\
$\alpha$-terpinolene & 15.645 & 2.678 & $\mathrm{C}_{10} \mathrm{H}_{16}$ & 136.23 \\
Cis-Sabinehydrate & 16.927 & 1.685 & $\mathrm{C}_{16} \mathrm{H}_{18} \mathrm{O}$ & 154.24 \\
Trans-4-Thujanol & 16.990 & 0.164 & $\mathrm{C}_{16} \mathrm{H}_{18} \mathrm{O}$ & 154.25 \\
Terpinene-4-ol & 21.287 & 23.86 & $\mathrm{C}_{16} \mathrm{H}_{18} \mathrm{O}$ & 154.25 \\
$\alpha$-Terpineol & $21 . .768$ & 6.421 & $\mathrm{C}_{12} \mathrm{H}_{20} \mathrm{O}$ & 196.29 \\
Linalyl acetate & 23.707 & 3.693 & $\mathrm{C}_{16} \mathrm{H}_{18} \mathrm{O}$ & 154.28 \\
$\beta$-Caryophllene & 30.974 & 4.820 & $\mathrm{C}_{15} \mathrm{H}_{24}$ & 204.35 \\
Spathulenol & 39.197 & 2.876 & $\mathrm{C}_{15} \mathrm{H}_{24} \mathrm{O}$ & 220.00 \\
\hline
\end{tabular}

$\mathrm{R}_{\mathrm{t}}=$ Retention time $\quad$ M. formula $=$ Molecular formula M.W. = Molecular weight

Table (6): Major compounds of Marjoram and Chamomile essential oil

\begin{tabular}{lcc}
\hline Compound & M.W. & $\mathrm{M} / \mathrm{Z}$ \\
\hline Terpinene -4-ol & 154 & $154-148-140-136-132-$ \\
& & $125-121-117-111-105-$ \\
& & $101-97-93-86-81-77-71-$ \\
& $67-63-59-55-51$ \\
Bisabolol oxide A & 238 & $143-132-125-119-107-$ \\
& & $99-93-85-79-71-65-$ \\
& & $59-55-53$ \\
\hline M.W = Molecular weight & $\mathrm{M} / \mathrm{Z}$ = Mass- To- charge ratio
\end{tabular}




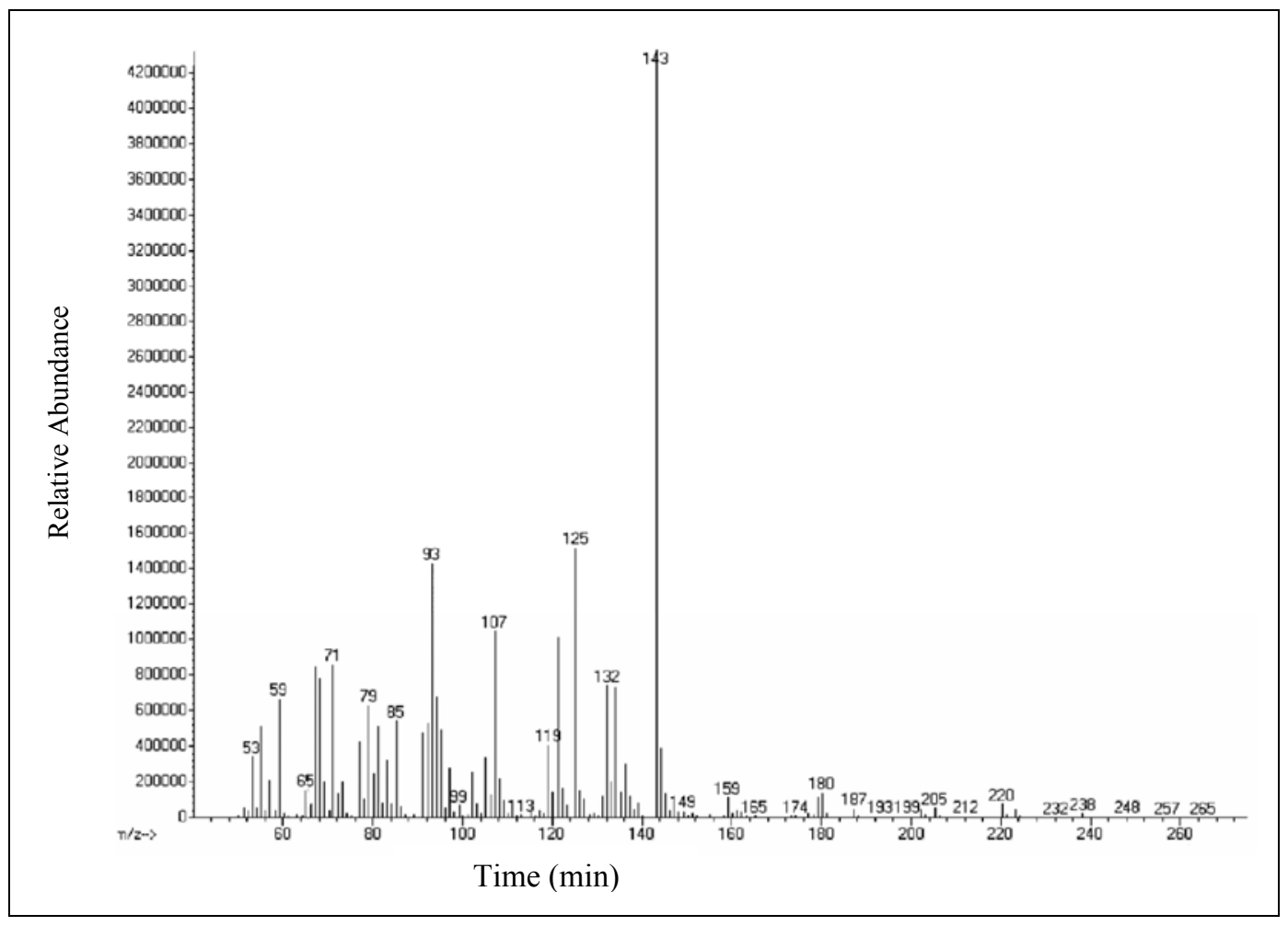

Fig. (1): Chromatogram of Bisabolol oxid A in Chamomile

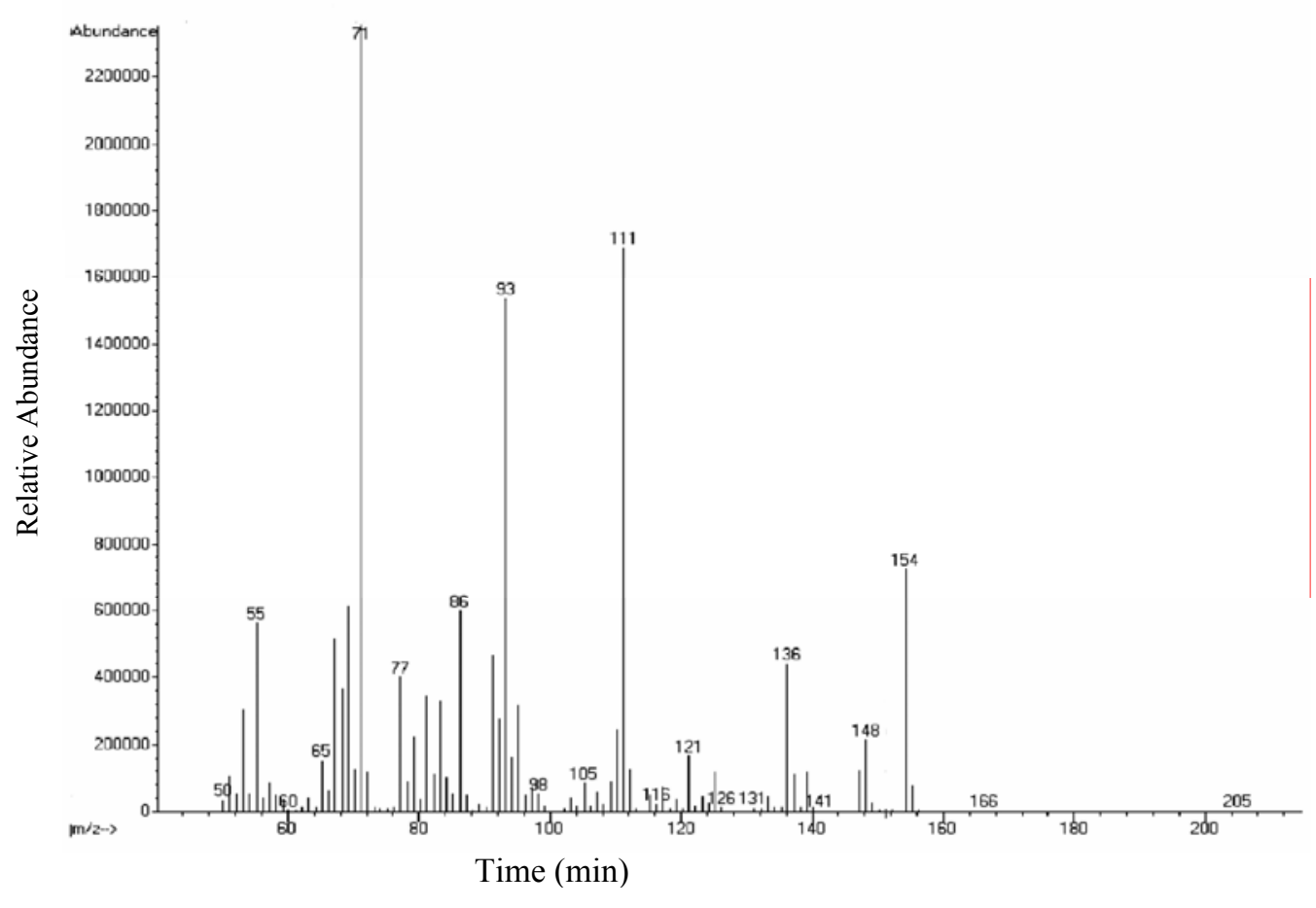

Fig. (2): Chromatogram of Terpinene-4-Ol in Marjoram 


\section{REFERENCES}

Abbot, W. S. 1925. A method of computing the effectveness of an insecticide. J. E con. Entomol., 18: 265-267.

Ali, Fatma. S. 2004. Toxicity of spinosad as novel bioinsectcide against Tetranychus urticae Koch. Ann. Agric. Sc., Moshtohor, 42 (1): 373-378.

Aslan, H.; Calmasur, N. and Sahn, F. 2004. Toxicity of essential oil vapours to two greenhouse pests, Tetranychus urticae Koch and Bemisia tabaci Genn. Industrial Crops and Products., 19(2): 167173.

Baker, E. M. 2003. Pytochemical toxicological studies on essential oil of aromatic plants against Tetranychus urticae Koch. Ph. D. Thesis, Fac. Agric., Cario Univ., 150 pp.

Busvine, J. R. 1971. The biochemical and gentic bases of insecicide resistance. PANS, 17(2): 135146.

Cao, H.; Wang, Y. N.; Liu, S.; Li, X. H. and Shi, G. L. 2003. Effects of Kochia scoparia extracts to activities of several enzymes of Tetranychus viennensis. Scientia Silvae Sinicae, 44(8): 62-66.

Carbras, P.; Cabni, P.; Carbras, M.; Angioni, A. and Russo, M. 2002. Rotenone residues on olives and in olive oil. J. Agric Food Chem., 50: 2576-2580.

Croft, B. A. 1977. Resistance in arthropod predators and parasites. in pesticide management and insecticide. Eds. D.L. Wats and A.W.A. Brown. Academic press, New Yourk.

Duncan, B. D. 1955. Multiple range and multiple Ftest Biometrics., 11: 1-42.

El-Halawany, M. E. and Sawires, Z. R. 1988. Biological and toxicological studies of certain plant extracts on Tetranychus urticae Koch. Bull. Zool. Soc., Egypt., 36: 37-41.

Finney, D. J. 197. Probit analysis. Cambridge Univ. Press, 333 pp.

Habig, W. H.; Pabst, M. J. and Jakoby, W. B. 1974. Glutathione S-transferase, the first step in mercapturic acid formatoin. J. Biol. Chem., 2497130.

Hoelzl, J. and Demuth, G. 1975. Influence of ecological factors on the composition of the essential oil and flavonoids in Matricaaria chamomilla of different origin. Planta Med., 27: 46-52.

Isman, M. B. 1997. Neem and other botanical Insectcide barriers to commercializtion. Phytoparasiticas, 25 (4): 339-344.

Kawka, B. 2004. Effect of chamomile extracts on biology of Tetranychus urticae Koch feeding on Algerian Ivy (Hedera canariensis L.). Annals of
Warsaw Agricultural University, Horticulture Landscape Architecture., 25:75-79.

Kostaropoulos, I.; Papadopoulos, A. I.; Metakis, A.; Boukouvala, E. and Papadopoulou-Mourkidou, E. 2001. Glutathione S- transferase in the defense againt pyrethrioids in insect. Insect Biochem. Mol. Biol., 31: 313-319.

Mansour, F. Ravid, U. and Putievsky, E. 1986. Studies of the effects of essential oils isolated from 14 species of Labiatae on carmine spider mite, Tetranychus cinnabarinus. Phytoparasitica., 14 (2): 137-142.

Mannervik, B. and Danielson, U. H. 1988. Glutathione transferase - catalytic activity. CRC Crit. Rev. Biochem., 23: 283-337.

Ma, Z. Q.; Feng, J. T.; Huang, S. Z. and Zhang, X. 2004. The effect of terpinen-4-ol on several enzymes in housefly, Musca domestica.ActaPhytophylacica-Sinica.,31(3): 283-288.

Ma, Z. Q.; Feng, J. T.; Guo, Z. B. and Zhang, X. 2008. Effects of terpinen-4-ol on four kinds of metabolizing enzymes and polyphenol oxidase in Musca domestica. Journal of Zhejiang University Agriculture and Life Sciences, 34(5): 509-515.

Motoyama, N. and Dauterman, W. C. 1980. Glutathione S- transferase : their role in the metabolism of organophosphorus insecticides .Rev. Biochem. Toxicol., 2: 49-69.

Pino, J. A.; Bayat, F.; Morbot, R. and Aguero, J. 2002. Essential oil of chamomile Chamomilla recutita (L.) Rausch. From Iran. J. Essent. Oil Res., 14: 407-408.

Powell, M. E. A. and Smith, M. J. H. 1954. The determination of serum acid and alkaline phosphatase activity with 4-aminoantipyrine. J. Clin. Pathol., 7: 245-248.

Sakunwarin, S.; Chandrapatya, A. and Visetson, S. 2004. Synergism and detoxification mechanism of crude sugar apple seed extract in Tetranychus truncates Ehara (prostigmata:Tetranychidae). Kasetsart J. (Nat. Sci.)., 38: 340-348.

Stark, J. D.; Vargas, R. I. and Thalman, R. K. 1990. Azardirachtin: effects on metamorphosis, longevity, and reproduction of three tephritid fruit fly species (Dipter: Tephritidae). J. Econ. Entomol., 83(6): 2168-217.

Stark, J. D.; Wong, T. T. Y.; Vargas, R. I. and Thalman, R. K. 1992. Survival, longevity and reproduction of tephritid fruit fly parasitoidas (Hymenoptera: Braconidae) reared from fruit flies exposed to azadirachtin J. Econ. Entomol., 84(4): 1125-1129.

Stumpf, N. and Nauen, R. 2002. Biochemical markers linked to abamectin resistance in Tetranychus urticae (Acari: Tetranychidae). 
Pesticide Biochemistry and Physiology, Phytoseiulus persimilis. Ecotoxicology and 72(2):111-121.

Enviroonmental safety, 70: 276-282.

Tsolakis, H. and Ragusa, S. 1999. Effetti dell "olio di neem (Azadirachta indica A. juss) su Bactrocer oleae (Gmelin) (Diptera,Tephritidae) in prove di labortorio e di campo. Phytophaga, 9 (Suppl.): 65-75.

Tsolakis, H. and Ragusa, S. 2008. Effect of mixture of vegetable and essential oils and fatty acid potassium salts on Tetranychus urticae and

Van Asperen, K. 1962. A study of housefly esterase by means of sensitive colourimetric method. J. Insect Physiol., 8: 401-416.

Wang, Y. N.; Miao, P. F.; Cao, H.; Liu, S. Q. and Shi, G. L. 2007. Effects of extracts of leaves of Juglans regia to several enzyme systems in Tetranychus cinnabarinus. Acta Horticulturae Sinica, 34. 